1 Submitted to: Arthropod Structure and Development

\title{
2 The basitarsal sulcus gland, a novel exocrine structure in ants
}

3 Johan Billen ${ }^{1}$, Adam Khalife ${ }^{2}$, Fuminori Ito ${ }^{3}$, Nguyen Duc Anh ${ }^{4}$ and Flavia A. Esteves ${ }^{5}$

$4{ }^{1}$ Zoological Institute, University of Leuven, Naamsestraat 59, box 2466, B-3000 Leuven,

5 Belgium. e-mail: johan.billen@kuleuven.be

${ }^{2}$ Sorbonne Université, CNRS, Institut d'Écologie et des Sciences de l'Environnement, 75005

7 Paris, France.

$8{ }^{3}$ Laboratory of Entomology, Faculty of Agriculture, Kagawa University, Ikenobe, Miki 761 -

9 0795, Japan

${ }^{4}$ Systematic Zoology Laboratory, Department of Biological Sciences, Tokyo Metropolitan

11 University, Tokyo 192-0397, Japan

${ }^{5}$ California Academy of Sciences, 55 Music Concourse Dr., San Francisco, CA 94941, U.S.A.

13 Keywords: morphology; histology; ultrastructure; basitarsus; exocrine glands

14 Running title: the sulcus gland, a novel exocrine structure in ants

15 Contact address:

Johan Billen, KU Leuven, Zoological Institute, Naamsestraat 59, box 2466, B-3000 Leuven,

17 Belgium

18 Tel :

(32) 16323975

19 Fax :

(32) 16324575

E-mail: johan.billen@kuleuven.be 


\section{Abstract}

The basitarsus of the mid- and/or hindlegs of several Amblyoponinae ants shows a deep longitudinal groove or sulcus on its anterior face in workers and queens. Histological examination reveals this sulcus is associated with a conspicuous novel epithelial gland, which brings the number of exocrine glands in the legs of ants to 25 . The ultrastructural characteristics of the gland show the presence of a well-developed smooth endoplasmic reticulum. This is indicative for the elaboration of a non-proteinaceous and thus possibly pheromonal secretion. Behavioural observations show that this secretion is collected by the tarsomeres and spread onto the brood and nest, suggesting a role in nestmate recognition. A similar basitarsal sulcus gland was also found in Nothomyrmecia, Paraponera and Tetraponera, which represents both a wide phylogenetic and ecological distribution, as it includes arboreal, ground-dwelling as well as subterranean taxa.

\section{Introduction}

Since the illustrious Carl Linnaeus introduced the binomial scientific names for animals and plants in the $18^{\text {th }}$ century, hundreds of thousands of such 'Latin names' have been given by taxonomists. The shortest animal species name is that of the greater evening bat la io in Southeast Asia, the tongue-twisting longest is given to Parastratiosphecomyia stratiosphecomyioides, a fly species in Thailand. The specific (second) part of the name often refers to an anatomical character (e.g., the ant Acromyrmex octospinosus has eight prominent spines on its thorax), reflects geographical distribution information (e.g., Atta texana), or has been given as a tribute to a person (e.g., Camponotus foreli, called in honour of the eminent Swiss myrmecologist Auguste Forel). An interesting example of anatomically informative specific names is found in the amblyoponine ant genus Stigmatomma, in which three species from Madagascar have been named according to the appearance of the basitarsus in their mid- and hindlegs using wording from Malagasy language (Esteves and Fisher, 2016): Stigmatomma roahady refers to the presence of a longitudinal sulcus or groove on the anterior face of both the meso- and metabasitarsus (roa means 'two', hady means 'sulcus'), S. irayhady displays such sulcus only on the mesobasitarsus (iray means 'one'), and S. tsyhady does not have any sulcus (tsy means 'absence'). 
The basitarsal sulcus is found in seven out of the eight Stigmatomma species occurring in the Malagasy region (Esteves and Fisher, 2016). A similar-shaped sulcus has been documented in the meso- and/or metabasitarsus of other Amblyoponinae (Fulakora chilensis, misidentified as F. armigera, F. mystriops, Stigmatomma pallipes, S. pluto, Myopopone castanea, and Xymmer muticus; Keller, 2011), as well as Myrmeciinae, Paraponerinae and Pseudomyrmecinae (Ward, 1990).

We here present a comparative study that checked for the presence of glandular tissue in the meso- and metabasitarsus of Amblyoponinae, Myrmeciinae, Paraponerinae, and Pseudomyrmecinae species, and describe a novel gland that is associated with the basitarsal sulcus. In addition, the availability of live Myopopone castanea allowed us to perform some behavioural observations related with their sulcus glands on the mid- and hindleg basitarsi.

\section{Material and methods}

A live queenright colony of Myopopone castanea was collected in Tay Yen Tu Nature Reserve (N21.17, E106.72), Bac Giang, Vietnam, in April 2017, and kept at $25^{\circ} \mathrm{C}$ in an artificial nest with plaster of Paris floor (for description, see Ito et al., 2020). Behavioural observations took place between April and June 2018, when the colony was queenless with approximately 80 workers. The ants were fed mealworms though workers mostly got their nutrients from larval hemolymph feeding (LHF: Ito, 2010). Eighteen workers were individualized with oil-based paint markers and observed between April $4^{\text {th }}$ and $11^{\text {th }}$. Then, between April $11^{\text {th }}$ and May $8^{\text {th }}, 40$ workers were followed for 10 minutes after they performed lateral leg-rubbing (LLR, see 3.3). Furthermore, 20 random workers were also followed for 10 minutes to compare behaviour with and without leg-rubbing. We tentatively coated the sulci in some workers with nail polish, with the expectation it would prevent secretion discharge and that the ants would in turn display some modified behaviour. Pictures and videos were taken using a handheld Canon EOS 550D (Tokyo, Japan) reflex camera equipped with a Canon EF $100 \mathrm{~mm} \mathrm{f} / 2.8 \mathrm{~L}$ USM macro lens.

Worker's basitarsi were cut off and fixed in $2.5 \%$ cold glutaraldehyde (in $0.1 \mathrm{M} \mathrm{Na}$ cacodylate buffer at $\mathrm{pH} 7.2$ ) for 12 hours. Postfixation was done in $2 \%$ cold osmium tetroxide for 1 hour, followed by dehydration in a graded acetone series and embedding in Araldite. Blocks were sectioned at a thickness of $1 \mu \mathrm{m}$ with a diamond knife using a Leica EM UC6 
ultramicrotome (Wetzlar, Germany) and stained with 1\% methylene blue. Serial semithin sections were examined with an Olympus BX-51 microscope (Tokyo, Japan) connected to a camera. Thin sections of $70 \mathrm{~nm}$ were double-stained with lead citrate and uranyl acetate and studied under a Zeiss EM900 electron microscope (Oberkochen, Germany). Similarly prepared basitarsi for histological and/or ultrastructural examination were also available for workers of Nothomyrmecia macrops (from Poochera, Australia), Onychomyrmex hedleyi (from Ravenshoe, Australia), Paraponera clavata (from Belém, Brazil), Stigmatomma roahady (from Andrambovato, Madagascar) and Tetraponera rufonigra (from Bangkok, Thailand).

Mounted specimens of several other species were obtained from the collections of the California Academy of Sciences, San Francisco, USA (Flavia Esteves) and Kagawa University, Takamatsu, Japan (Fuminori Ito). Details of all ant material used in this study are provided in Supplementary Table S1. The presence of a basitarsal sulcus was evaluated under a stereoscope (Leica M205C, Leica Microsystems, Switzerland) and through electron microscopy. Samples for scanning microscopy were mounted on aluminium stubs, coated with gold-palladium, and viewed under a Hitachi SU3500 (Hitachi High-Technologies, Japan) and a JEOL JSM-6360 scanning microscope (Tokyo, Japan). Note that micrographs of specimens bearing "AntWeb" labels were originally produced by Keller (2011), and are available on AntWeb.org (AntWeb, 2020).

\section{Results}

As the initial inspiration for our paper was a taxonomic revision of the genus Stigmatomma in the Malagasy region (Esteves and Fisher, 2016), we first made a comparative study to check for the presence of a basitarsal sulcus across the genus Stigmatomma. Checking 23 species with worldwide distribution (see Supplementary Table S2) revealed that a sulcus is present on the midleg basitarsi in almost all species (Fig. 1). The sulcus is present in both workers and queens, but seems variable in males, where it may be long, very short or just absent. The sulcus appears as a straight longitudinal groove on the anterior face of the basitarsus that runs along the central portion ( $S$. roahady), proximal portion (S. tsyhady and S. liebe) or almost the entire length of the mesobasitarsus (the majority of species). Only $S$. roahady has a similar sulcus also on the metabasitarsus (Fig. 1B). The only species without any basitarsal sulcus are $S$. reclinatum, $S$. rothneyi, and $S$. tsyhady. In $S$. besucheti, the sulcus is more curved (Fig. 1K), while $S$. luyiae (only known from 
112 Taiwan) presents on the anterior face of the basitarsus of its midlegs a round concavity filled with short rod-like cuticular projections (Fig. 1L).

Following Keller (2011), we extended our observations to species of other Amblyoponinae, and confirmed the presence of a longitudinal sulcus on the mesobasitarsus in females of Myopopone (which have such sulcus also on the metabasitarsus, Fig. 2A-C), Fulakora and Xymmer (Fig. 2D-F; Supplementary Table S2). Contrary to Keller (2011) though, we found that the mesobasitarsal sulcus is present in Adetomyrma workers and queens (Fig 2D). The sulcus is absent in Amblyopone, Mystrium, Prionopelta, and Onychomyrmex, as also observed by Keller (2011). Onychomyrmex, however, has a peculiar oval concavity surrounding rod-like cuticular projections on the ventrodistal face of the metabasitarsus (Fig. 2G, see also Hölldobler and Palmer, 1989a), and which appears similar to what is seen in Stigmatomma luyiae (Fig. 1L). In some Prionopelta species, a very small transverse sulcus of hardly $3 \mu \mathrm{m}$ exists on the ventrodistal region of the hindleg of workers and queens (Hölldobler et al., 1992; Ito and Billen, 1998).

The presence of a basitarsal sulcus is not only restricted to Amblyoponinae. We confirm a similar sulcus on the anterior face of both the midleg and hindleg basitarsi in several Myrmecia species and Nothomyrmecia macrops (Myrmeciinae, Fig. 3A,B), and Paraponera clavata (Paraponerinae, Fig. 3C). In Pseudomyrmecinae, the sulcus is present on the mesoand metabasitarsus of Myrcidris epicharis and in all species of Tetraponera we examined save $T$. attenuata, which did not present the sulcus on the mesobasitarsus (Fig. 3D; Supplementary Table S2).

\subsection{Light microscopy}

Histological sections of the basitarsus show the longitudinal sulcus as a deep groove with a width of 5-10 $\mu \mathrm{m}$, lined by an invagination of the thick basitarsal cuticular wall. The depth of the groove varies according to the size of the ants, ranging from 5-10 $\mu \mathrm{m}$ in the smaller Stigmatomma up to $50 \mu \mathrm{m}$ in the giant Paraponera. Along its entire length, no matter whether it occurs in the midleg or hindleg, the sulcus is internally lined by a conspicuous glandular epithelium with tall cylindrical cells (Fig. 4A-F). The thickness of the epithelium depends on the size of the ant and ranges between 15 and $50 \mu \mathrm{m}$, whereas the non-glandular epidermis elsewhere in the basitarsus hardly reaches a thickness of 2-3 $\mu \mathrm{m}$ (Fig. 4A-F). The round nucleus has a diameter around $5 \mu \mathrm{m}$ and is basally located (Fig. 4A-F). 
Sections through the oval metabasitarsal sulcus in Onychomyrmex (and also through the region with the small transverse metabasitarsal sulcus in Prionopelta, see Hölldobler et al., 1992; Ito and Billen, 1998) revealed the presence of glandular tissue, although this appears clearly different from the characteristic epithelium as described above (Fig. 4G). Contrary to the sulcus gland epithelium, the gland cells in Onychomyrmex contain numerous spherical lipid droplets and display a capricious connection with the cuticle (Fig. 4G).

\subsection{Electron microscopy}

Ultrastructural examination confirms the glandular nature of the sulcus epithelium. The thick cuticle overlaying the epithelium displays an irregular texture that forms transcuticular channels for the passage of the secretory products (Fig. 5A,B). At the bottom of the sulcus, minuscule depressions are seen at the apical side of the cuticle (Fig. 5A inset). The apical cell membrane of the epithelial cells is differentiated into a clear microvillar border (Fig. 5A,B). The cytoplasm is characterized by a well-developed smooth endoplasmic reticulum (Fig. $5 \mathrm{C}, \mathrm{D})$, although some local accumulations of rough endoplasmic reticulum can also be found (Fig. 5C). Further obvious cytoplasmic organelles include Golgi apparatus and numerous dark-staining mitochondria (Fig. 5C-E). The basal cell membrane shows irregular invaginations, while a thin amorphous basement membrane of $50 \mathrm{~nm}$ separates the epithelium from the underlaying hemolymph space (Fig. 5E).

\subsection{Behavioural observations}

Our observations of a captive colony of Myopopone castanea indicate that secretions from the meso- and metabasitarsi were spread on the tarsomeres and gaster tip through a particular behaviour that we refer to as leg-rubbing (LR). This behaviour can sometimes be observed in other ant species while they groom (e.g., genus Carebara; Khalife, pers. obs.). In M. castanea, however, LR was observed exclusively in the nest and occurred so frequently that all attempts to coat the sulcus with nail polish failed because it could not dry. We observed two types of LR. In the lateral leg-rubbing (LLR), which was commonly observed and could last from a few seconds to 7 minutes, tarsomeres of both forelegs rubbed the basitarsus of ipsilateral mid- and hindlegs while the remaining legs acted as stands to support the body (Fig. 6A). In the posterior leg-rubbing (PLR), which was observed less frequently and only lasted a few seconds, both hindlegs were rubbed against each other underneath the gaster while the worker stood on its four other legs (Fig. 6B). Slow-motion playback of LLR 
and PLR recordings confirmed that the tarsomeres directly touched the sulcus area during both types of LR (see Supplementary Videos 1 and 2).

We monitored the activity of workers for 10 minutes after performing lateral leg-rubbing (LLR group) or during random 10-minute intervals (control group; see Supplementary Table S3). In the control group, three workers out of 20 performed LLR, PLR or both and were thus removed from our dataset. In the LLR group, workers performed LLR again in $60 \%$ of the observations and PLR in 55\%. Brood care was observed more often in the LLR group (50\% of the observations) compared to the control group (18\%). Larval care was particularly important: a single worker groomed and patted up to 14 larvae in a 10-minute interval. Workers walked around in the nest less frequently in the LLR group than in the control group (50\% of the observations compared to $82 \%$ ). Grooming of a nestmate worker was rarely observed in both groups ( $15 \%$ for the LLR group, $12 \%$ for the control group). In the LLR group, $13 \%$ of the workers went outside the nest compared to none in the control group. Larval hemolymph feeding (LHF) never happened in any of our 60 observations, but cooccurrence of LR and LHF was observed twice apart from these trials. In the first case, a worker repeatedly performed consecutive LLR and self-grooming while feeding on the hemolymph of a single larva. In the second case, another worker performed LLR, brood care and LHF, then groomed a nestmate and repeated this sequence on another larva.

\section{Discussion}

The presence of an extraordinary diversity of exocrine glands in social insects, and in ants in particular, is commonly known (Hölldobler and Wilson, 1990; Billen and Šobotník, 2015). In their legs only, ants can have 20 different glands (Billen, 2009). This astonishing number has increased to 24 with the description of a footsole gland in the hindleg distal tarsomeres of Protanilla wallacei (Billen et al., 2013) and the recent discovery of 3 glands in the foreleg coxae of Discothyrea ants (Billen et al., 2020). The present description of the novel basitarsal sulcus gland therefore represents the $25^{\text {th }}$ leg gland so far known in ants.

The structural characteristics of the basitarsal sulcus gland correspond with class-1 glands according to the standard classification by Noirot and Quennedey (1974), in which epithelial secretory cells accumulate the precursor molecules from the underlaying hemolymph space and metabolize them into the final secretory products, which are eventually 
discharged to the outside through the external cuticle. This transepithelial transport is facilitated by obvious surface-increasing basal invaginations as well as apical microvilli. The irregular texture and minuscule slits on the surface of the cuticle overlaying the glandular epithelium (see Fig. 5 inset) provides a trajectory for the secretion to reach the outside. Similar cuticular modifications for class-1 glands have also been reported for several other leg glands in ants (Billen, 2009), for the mandibular pit gland in Brachyponera sennaarensis (Billen and Al-Khalifa, 2016) and for the basimandibular gland in Strumigenys (Wang et al., 2021). The cytoplasm is mainly dominated by smooth endoplasmic reticulum and Golgi apparatus, which is indicative for a non-proteinaceous, and hence likely pheromonal secretion (see further).

In spite of the impressive number of glands that can be found in the legs of ants, little is known about their function other than producing lubricants for the leg articulations (Billen, 2009). The best documented exceptions are the hindleg glands that produce trail pheromones: the tibial glands in Crematogaster (Leuthold, 1968), the pretarsal footprint glands in Amblyopone australis (Hölldobler and Palmer, 1989b) and Stigmatomma reclinatum (formerly Amblyopone reclinata: Billen et al., 2005), and the basitarsal glands in Onychomyrmex sp. (Hölldobler and Palmer, 1989a) and Prionopelta amabilis (Hölldobler et al., 1992). Another example of a hindleg gland with known function is found in some species of Diacamma that reproduce through mated workers, or garmegates. In those species, virgin unmutilated workers attract males with a sex pheromone produced by their metatibial gland in an attempt to mate (Hölldobler et al., 1996; Nakata et al., 1998). The forelegs in many ant species contain a basitarsal 'antenna cleaner gland' (Schönitzer et al., 1996), although it remains unclear whether it really plays a role in antennal cleaning. None of the midleg glands, however, has so far been associated with a particular function in any ant species. Even though behavioural observation of Myopopone castanea failed to precisely characterize the function of the basitarsal sulcus gland, it narrowed down the possibilities. First, this novel gland could have a cicatrizing function related to LHF, and if so, ants would likely perform LR after larval hemolymph feeding (LHF). However, ants performed LR at a much higher frequency than LHF, and co-occurrence of both was not observed in any of our 10-minute trials, which makes a cicatrizing function unlikely. The two workers seen performing LR and LHF successively also groomed themselves, brood, or a nestmate worker, thus LR could be linked to these particular tasks. Second, LR transferred secretions of the basitarsal sulcus 
gland to the gaster, which could suggest a trail pheromone, although trail-laying has never been reported in $M$. castanea. Nonetheless, LR was observed frequently even though workers rarely went outside the nest during our laboratory observations, which weakens such a hypothesis on the function of the basitarsal sulcus gland. In sharp contrast, following LR, workers often groomed and patted the brood, especially the larvae. This observation, along with the ultrastructural characteristics that indicate the elaboration of a non-proteinaceous secretion, suggest that the sulcus gland produces pheromones responsible for nestmate recognition ("colony smell”), possibly cuticular hydrocarbons (CHCs). While an early study suggested that $\mathrm{CHCs}$ were produced by the pharyngeal gland in ants (Bagnères and Morgan, 1991), a sequestering rather than secretory function of this gland has become apparent later on (Lucas et al. 2004), and that instead, CHCs are produced by subepithelial glands (Gobin et al., 2003). It is unclear if the basitarsal sulcus gland compensates or supplements the subepithelial gland's secretion. According to the presence/absence of the basitarsal sulcus (Supplementary Table S2) and data provided by Gobin et al. (2003), the two glands co-occur in Myopopone castanea, Myrmecia gulosa, M. pyriformis, and Nothomyrmecia macrops, but only the basitarsal sulcus is present in Myrmecia simillima and in M. vindex. The subepithelial gland is present while the basitarsal sulcus is absent in an undescribed species of Pseudomyrmex, and both traits are absent in Mystrium camillae, Prionopelta kraepellini, and Stigmatomma reclinatum. Finally, the occurrence of leg-rubbing behaviour in other ant taxa with and without a basitarsal sulcus gland remains to be investigated.

The distribution of a basitarsal sulcus gland, scattered in two major clades of the ant tree of life, suggests either convergence or single origin followed by multiple losses. Amblyoponinae and Paraponerinae, plus Agroecomyrmecinae, Apomyrminae, Ponerinae, and Proceratiinae form the Poneroid clade, and Myrmeciinae and Pseudomyrmecinae are classified in the Formicoid clade, which also includes the subfamilies Aneuretinae, Dolichoderinae, Dorylinae, Ectatomminae, Formicinae, Heteroponerinae, and Myrmicinae (Borowiec et al., 2020). The relationships among the poneroid subfamilies are still inconclusive (Borowiec et al., 2020), which obscures the degree of relatedness between Amblyoponinae and Paraponerinae. Within Amblyoponinae, the basitarsal sulcus is present in workers and queens of all lineages that make up the XMMAS-clade (Xymmer, Myopopone, Adetomyrma, Stigmatomma, and Fulakora) save Mystrium, and it is absent in the clade Amblyopone + Prionopelta + Onychomyrmex (for the evolutionary history of Amblyoponinae 
see Ward and Fisher, 2016). Of these, Onychomyrmex (Hölldobler and Palmer, 1989a) and Prionopelta (Hölldobler et al., 1992; Ito and Billen, 1998) have a gland on the ventrodistal portion of the hindleg basitarsus. This metabasitarsal gland, however, does not display the typical epithelial features nor the external longitudinal sulcus appearance, and therefore cannot be considered homologous to the novel sulcus gland we here describe. An interesting case in this regard is Stigmatomma luyiae, which has a round mesobasitarsal sulcus that externally much resembles the metabasitarsal structure of Onychomyrmex with similar rodlike cuticular projections (compare figs. $1 \mathrm{~L}$ and $2 \mathrm{G}$ ). A study in four amblyoponine genera (Mystrium, Onychomyrmex, Prionopelta and Stigmatomma) by Schoeters et al. (1999) revealed that ants of this subfamily, similar to the situation in mutillid wasps, are unique in having a venom gland that lacks a convoluted gland portion. This lacking of a convoluted gland was also confirmed for Myopopone (Ito, unpubl. obs.), and together with the variation in the appearance of their sulcus gland illustrates the peculiarity of the subfamily Amblyoponinae. The relationships within the Formicoid clade are well-resolved, and phylogenetic inferences (Moreau and Bell, 2013; Branstetter et al., 2017; Borowiec et al., 2020). In fact, Bolton (2003) considered the metabasitarsal sulcus a synapomorphy of the clade formed by these two subfamilies, which he called myrmeciomorph. Noteworthy in this discussion is the predominantly arboreal Dorylinae Simopone, whose females in all species present a longitudinal sulcus on the ventral face of the metabasitarsus similar to what is seen in the subfamilies that possess the basitarsal sulcus gland (Bolton and Fisher, 2012); the sulcus is absent in males (Borowiec, 2016). In Myrmeciinae, the basitarsal sulcus is present in the meso- and metabasitarsus in females of Myrmecia, Nothomyrmecia (Ogata, 1991), and the extinct Prionomyrmex (Ward and Brady, 2003). Within Pseudomyrmecinae, a meso- as well as a metabasitarsal sulcus are present in the females of Myrcidris epicharis and are completely absent in its sister lineage, Pseudomyrmex (Ward, 1990), while most Tetraponera species have a metabasitarsal (and often also mesobasitarsal) sulcus in both workers and queens, but not in the males (Ward, 1990).

Finally, the novel basitarsal sulcus gland has a remarkable ecological distribution, occurring in arboreal, ground-dwelling as well as subterranean taxa. While Amblyoponinae ants are predominantly cryptic predators in the soil, rotten wood and leaf-litter in tropical and subtropical forests around the world, the neotropical Paraponera clavata conspicuously 
forages above the ground, from the forest floor to tree canopies, and feeds on a variable diet that includes invertebrates, small vertebrates, carrion, and extrafloral nectar (Brown, 1960; Delsinne et al., 2019, and references therein). The extant Myrmeciinae are distributed in the Australasia region. Myrmecia species forage above the ground for nectar and arthropod prey in habitats ranging from deserts to rainforests (Haskins and Haskins, 1950). Nothomyrmecia macrops forage on trees for insect prey, also feeding on sugary substances when available in the Mallee Woodlands in southern Australia (Hölldobler and Wilson, 1990). Myrcidris epicharis forage on its myrmecophyte hosts Myrcia madida and M. magna in the Amazon rainforest, and likely feeds on scale insects' exudates (Ferreira and Vasconcelos, 2010; Gaem et al., 2019). Tetraponera is widespread in the Old-World tropics, and may forage on vegetation or on ground in habitats that range from urban parks, to deserts, to grasslands, to rainforests, feeding on exudates or preying on other arthropods (Russell et al., 2009; Brian L. Fisher, pers. comm.).

\section{Acknowledgements}

We dedicate this paper to the memory of our dear friend and colleague Christian Peeters. We greatly appreciate the assistance of An Vandoren in section preparation for light and electron microscopy and to Alex Vrijdaghs for his help in scanning microscopy. Thanks are also due to Hiroki Miyata for collecting Onychomyrmex hedleyi and to Prof. Nguyen Van Sinh (Director Institute of Ecology and Biological Resources, Vietnam), Mr. Nguyen Dac Dai (IEBR), the director and staff of Tay Yen Tu Nature Reserve (Vietnam), and to Dr. Katsuyuki Eguchi (Tokyo Metropolitan University, Japan) for their continuous support. Malagasy specimens would not be accessible without the gracious support of the Madagascar Biodiversity Center team: Balsama Rajemison, Jean-Claude Rakotonirina, Hanitriniana Rasoazanamavo, Nicole Rasoamanana, Njaka Ravelomanana, Manoa Ramamonjisoa, JeanJacques Rafanomezantsoa (JJ), Chrislain Ranaivo, Clavier Randrianandrasana, and Bemaheva Fidelisy (Fidel). We also acknowledge the formidable support of Michele Esposito in imaging and databasing ants at the California Academy of Sciences. The research in Vietnam received support through grants for Oversea Research (B 24405010; B16H05769) from JSPS. 
AntWeb, 2020. AntWeb version 8.46.1. California Academy of Science, online at https://www.antweb.org. Accessed 14 December 2020.

Bagnères, A.G. and Morgan, E.D., 1991. The postpharyngeal glands and the cuticle of Formicidae contain the same characteristic hydrocarbons. Experientia 47, 106-111. https://doi.org/10.1007/BF02041269

Billen, J., 2009. Occurrence and structural organization of the exocrine glands in the legs of ants. Arthropod Struct. Dev. 38, 2-15. https://doi.org/10.1016/j.asd.2008.08.002

Billen, J. and Šobotník, J., 2015. Insect exocrine glands. Arthropod Struct. Dev. 44, 399-400. https://doi.org/10.1016/j.asd.2015.08.010

Billen, J. and Al-Khalifa, M.S., 2016. A novel intramandibular gland in the ant Brachyponera sennaarensis. Insect. Soc. 63, 321-326. https://doi.org/10.1007/s00040-016-0471-5

Billen, J., Bauweleers, E., Hashim, R. and Ito, F., 2013. Survey of the exocrine system in Protanilla wallacei (Hymenoptera, Formicidae). Arthropod Struct. Dev. 42, 173-183. https://doi.org/10.1016/j.asd.2013.01.001

Billen, J., Thys, B., Ito, F. and Gobin, B., 2005. The pretarsal footprint gland of the ant Amblyopone reclinata (Hymenoptera, Formicidae) and its role in nestmate recruitment. Arthropod Struct. Dev. 34, 111-116. https://doi.org/10.1016/j.asd.2004.11.003 Billen, J., Lin, C.-C. and Esteves, F.A., 2020. Novel exocrine glands in the foreleg coxae of Discothyrea ants. Arthropod Struct. Dev. 59, 100981. https://doi.org/10.1016/j.asd.2020.100981

Bolton, B., 2003. Synopsis and classification of Formicidae. Mem. Am. Entomol. Inst. 71, 1370.

Bolton, B. and Fisher, B.L., 2012. Taxonomy of the cerapachyine ant genera Simopone Forel, Vicinopone gen. n. and Tanipone gen. n. (Hymenoptera: Formicidae). Zootaxa 3283, 1101. https://doi.org/10.11646/zootaxa.3283.1.1

Borowiec, M.L., 2016. Generic revision of the ant subfamily Dorylinae (Hymenoptera, Formicidae). ZooKeys 608, 1-280. https://doi.org/10.3897/zookeys.608.9427

Borowiec, M.L., Rabeling, C., Brady, S.G., Fisher, B.L., Schultz, T.R. and Ward, P.S., 2020. Compositional heterogeneity and outgroup choice influence the internal phylogeny of the ants. Mol. Phylogenet. Evol. 134, 111-121. https://doi.org/10.1016/j.ympev.2019.01.024 Branstetter, M.G., Longino, J.T., Ward, P.S. and Faircloth, B.C., 2017. Enriching the ant tree of life: enhanced UCE bait set for genome-scale phylogenetics of ants and other Hymenoptera. Methods Ecol. Evol. 8, 768-776. https://doi.org/10.1111/20141-210X.12742 
Delsinne, T., Sonet, G. and Arias-Penna, T.M., 2019. Subfamilia Paraponerinae. In: Fernández, F., Guerrero, R.J. and Delsinne, T. (Eds). Hormigas de Colombia. Universidad Nacional de Colombia, Bogotá, pp. 637-657.

Esteves, F. and Fisher, B., 2016. Taxonomic revision of Stigmatomma Roger (Hymenoptera: Formicidae) in the Malagasy region. Biodivers. Data J. 4, e8032. https://doi.org/10.3897/BDJ.4.e8032.

Ferreira, L.V. and Vasconcelos, H.L., 2010. On a poorly known Amazonian ant-plant association: Myrcia madida McVaugh (Myrtaceae) and Myrcidris epicharis Ward (Hymenoptera: Formicidae: Pseudomyrmecinae). Bol. Mus. Para. Emílio Goeldi Sér. ciênc. nat. 5, 363-367.

Gaem, P.H., Farroñay, F., Ferreira dos Santos, T., Cabello, N., Mazine, F. and Vicentini, A., 2019. First record of Myrcia magna D.Legrand (Myrtaceae) as a myrmecophyte host for Myrcidris epicharis Ward, 1990 (Formicidae: Pseudomyrmecinae). Sociobiology 66, 592. https://doi.org/10.13102/sociobiology.v66i4.4477.

Gobin, B., Ito, F. and Billen, J., 2003. The subepithelial gland in ants: a novel exocrine gland closely associated with the cuticle surface. Acta Zool. (Stockholm) 84, 285-291. https://doi.org/10.1046/j.1463-6395.2003.00149.x

Haskins, C.P. and Haskins, E.F., 1950. Notes on the biology and social behavior of the archaic ponerine ants of the genera Myrmecia and Promyrmecia. Ann. Entomol. Soc. Am. 43, 461-491. https://doi.org/10.1093/aesa/43.4.461

Hölldobler, B. and Palmer, J.M., 1989a. A new tarsal gland in ants and the possible role in chemical communication. Naturwissenschaften 76, 385-386. https://doi.org/10.1007/BF00366215

Hölldobler, B. and Palmer, J.M., 1989b. Footprint glands in Amblyopone australis (Formicidae, Ponerinae). Psyche 96, 111-121. https://doi.org/10.1155/1989/70562 Hölldobler, B., Obermayer, M. and Peeters, C., 1996. Comparative study of the metatibial gland in ants (Hymenoptera, Formicidae). Zoomorphology 116, 157-167. https://doi.org/10.1007/BF02527156

Hölldobler, B., Obermayer, M. and Wilson, E.O., 1992. Communication in the primitive cryptobiotic ant Prionopelta amabilis (Hymenoptera: Formicidae). J. Comp. Physiol. 170A, 9-16. https://doi.org/10.1007/BF00195956

Hölldobler, B. and Taylor, R.W., 1983. A behavioral study of the primitive ant Nothomyrmecia macrops Clark. Insect. Soc. 30, 384-401. https://doi.org/10.1007/BF02223970 
Hölldobler, B. and Wilson, E.O., 1990. The Ants. Cambridge, Mass.: Harvard University Press, pp. 732.

Ito, F., 2010. Notes on the biology of the Oriental amblyoponine ant Myopopone castanea: Queen-worker dimorphism, worker polymorphism and larval hemolymph feeding by workers (Hymenoptera: Formicidae). Entomol. Sci. 13, 199-204. https://doi.org/10.1111/j.1479-8298.2010.00384.x

Ito, F. and Billen, J., 1998. Larval hemolymph feeding and oophagy: behavior of queen and workers in the primitive ponerine ant Prionopelta kraepelini (Hymenoptera, Formicidae). Belg. J. Zool. 128, 201-209.

Ito, F., Nguyen, D.A., Eguchi, K., Toyota, A. and Billen, J., 2020. Colony composition, queen behavior, specialized predation on millipedes, and exocrine glands in the ponerine ant Myopias conicara Xu, 1998 (Hymenoptera: Formicidae). Entomol. Sci. 23, 142-151. https://doi.org/10.1111/ens.12406

Keller, R.A., 2011. A phylogenetic analysis of ant morphology (Hymenoptera: Formicidae) with special reference to the poneromorph subfamilies. Bull. Am. Mus. Nat. Hist. 355, 1-90. https://doi.org/10.1206/355.1

Leuthold, R.H., 1968. A tibial gland scent-trail and trail-laying behavior in the ant Crematogaster ashmeadi Mayr. Psyche 75, 233-248. https://doi.org/10.1155/1968/73761

Lucas, C., Pho, D.B., Fresneau, D. and Jallon, J.M., 2004. Hydrocarbon circulation and colonial signature in Pachycondyla villosa. J. Insect Physiol. 50, 595-607. https://doi.org/10.1016/j.jinsphys.2004.04.006

Moreau, C.S. and Bell, C.D., 2013. Testing the museum versus cradle tropical biological diversity hypothesis: phylogeny, diversification, and ancestral biogeographic range evolution of the ants. Evolution 67, 2240-2257. https://doi.org/10.1111/evo.12105

Nakata, K., Tsuji, K., Hölldobler, B. and Taki, A., 1998. Sexual calling by workers using the metatibial glands in the ant, Diacamma sp., from Japan (Hymenoptera: Formicidae). J. Insect Behav. 11, 869-877. https://doi.org/10.1023/A:1020816227912

Noirot, C. and Quennedey, A., 1974. Fine structure of insect epidermal glands. Annu. Rev. Entomol. 19, 61-80. https://doi.org/10.1146/annurev.en.19.010174.000425

Ogata, K., 1991. Ants of the genus Myrmecia Fabricius: a review of the species groups and their phylogenetic relationships (Hymenoptera: Formicidae: Myrmeciinae). Syst. Entomol. 16, 353-381. https://doi.org/10.1111/j.1365-3113.1991.tb00694.x 
428

429

430

431

432

433

434

435

436

437

438

439

440

441

442

443

444

445

446

447

448

449

450

Russell, J.A., Moreau, C.S., Goldman-Huertas, B., Fujiwara, M., Lohman, D.J. and Pierce, N.E., 2009. Bacterial gut symbionts are tightly linked with the evolution of herbivory in ants. P. Natl Acad. Sci. U.S.A. 106, 21236-21241. https://doi.org/10.1073/pnas.0907926106

Schoeters, E., Ito, F., Miyata, H. and Billen, J., 1999. Aberrant venom glands in Amblyoponini (Formicidae, Ponerinae): morphology, ultrastructure and histochemistry. Acta Zool. (Stockholm) 80, 3-9. https://doi.org/10.1046/j.1463-6395.1999.20001.x

Schönitzer, K., Dott, H. and Melzer, R.R., 1996. The antenna cleaner gland in Messor rufitarsis (Hymenoptera, Formicidae). Tissue Cell 28, 107-113. https://doi.org/10.1016/S0040-8166(96)80049-8

Wang, C., Steenhuyse-Vandevelde, M., Lin, C.-C. and Billen, J., 2021. Morphology of the novel basimandibular gland in the ant genus Strumigenys (Hymenoptera, Formicidae). Insects 12, 50.

Ward, P.S., 1990. The ant subfamily Pseudomyrmecinae (Hymenoptera: Formicidae): generic revision and relationship to other formicids. Syst. Entomol. 15, 449-489. https://doi.org/10.1111/j.1365-3113.1990.tb00077.x

Ward, P.S. and Brady, S.G., 2003. Phylogeny and biogeography of the ant subfamily Myrmeciinae (Hymenoptera: Formicidae). Invertebr. Syst. 17, 361-386. https://doi.org/10.1071/IS02046

Ward, P.S. and Fisher, B.L., 2016. Tales of dracula ants: the evolutionary history of the ant subfamily Amblyoponinae (Hymenoptera: Formicidae). Syst. Entomol. 41, 683-693. https://doi.org/10.1111/syen.12186 


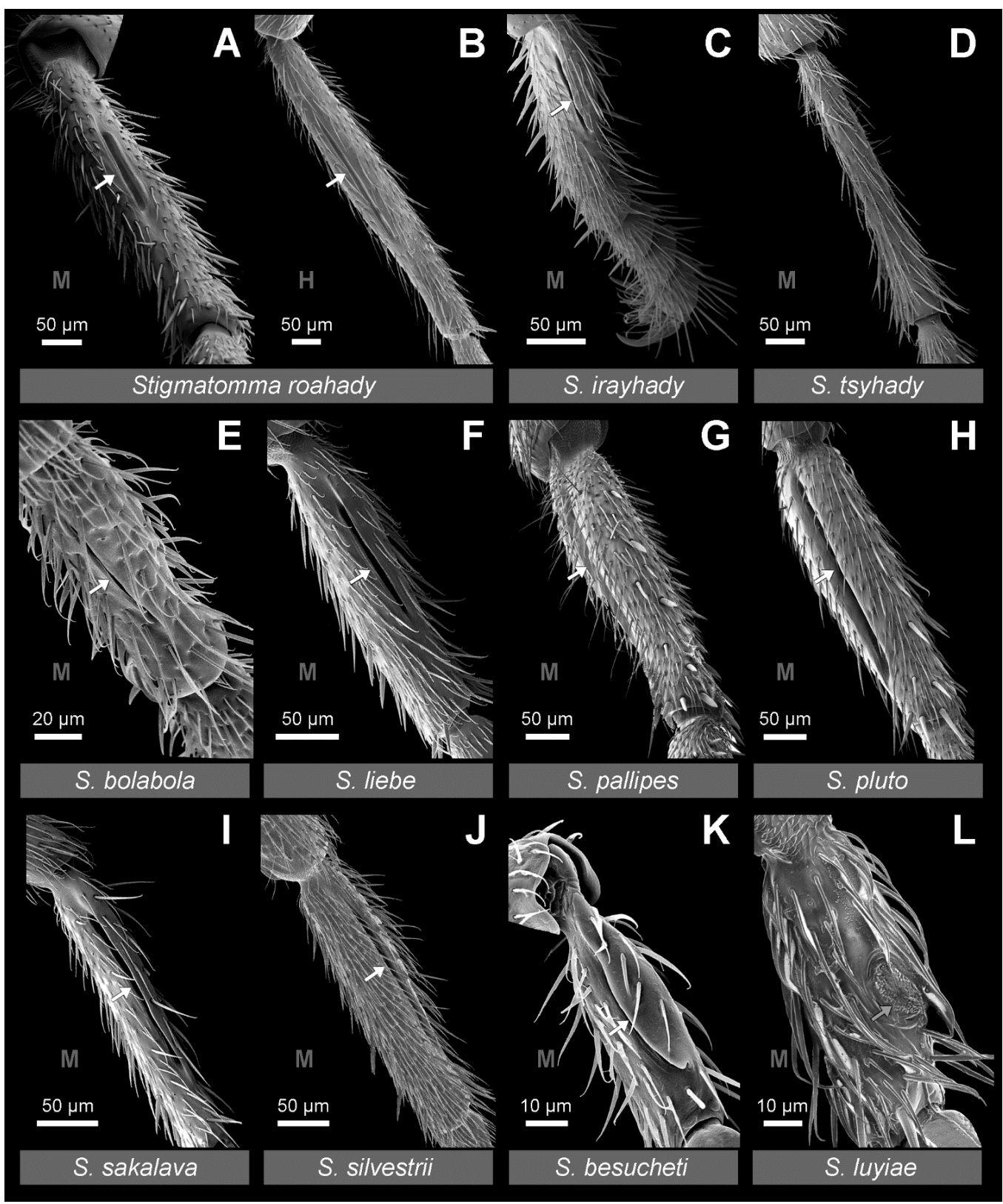

453 Fig. 1. Scanning micrographs of anterior face of basitarsus in workers of various Stigmatomma 454 species, white arrows indicate the basitarsal sulcus (grey $\mathrm{M}$ and $\mathrm{H}$ indicate midleg and hindleg 455 basitarsus, respectively). Note absence of sulcus in $S$. tsyhady (D), and circular plate (grey 456 arrow) in S. luyiae (L). 


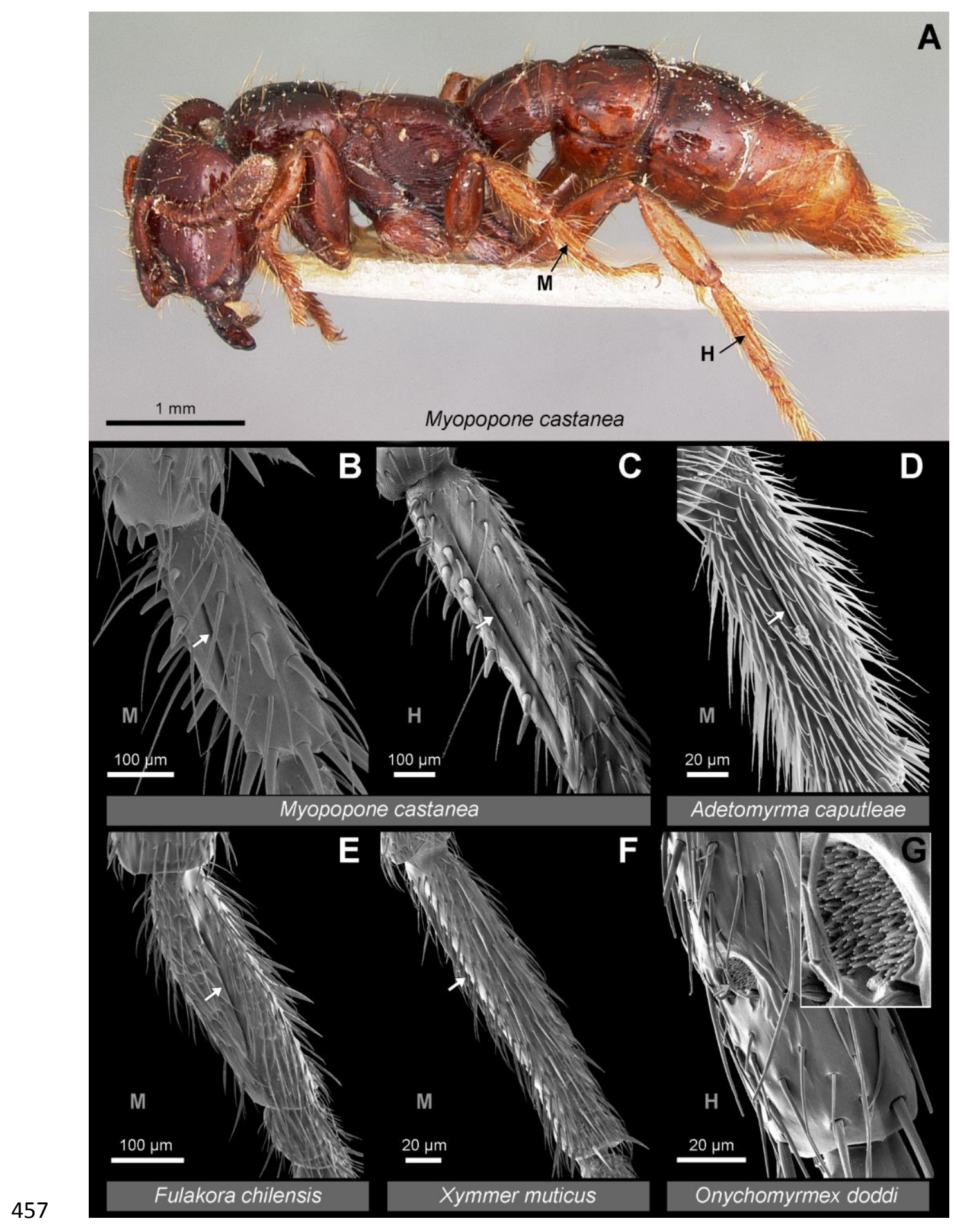

458 Fig. 2. A. Profile view of Myopopone castanea worker with arrows indicating sulcus on both 459 midleg and hindleg basitarsus. B-G. Scanning micrographs of anterior face of basitarsus in 460 various amblyoponine workers, white arrows indicate sulcus (grey $\mathrm{M}$ and $\mathrm{H}$ indicate midleg and 461 hindleg basitarsus, respectively). Note oval basitarsal sulcus indicated by grey arrow in 462 Onychomyrmex doddi $(\mathrm{G})$, with close-up view in inset. 


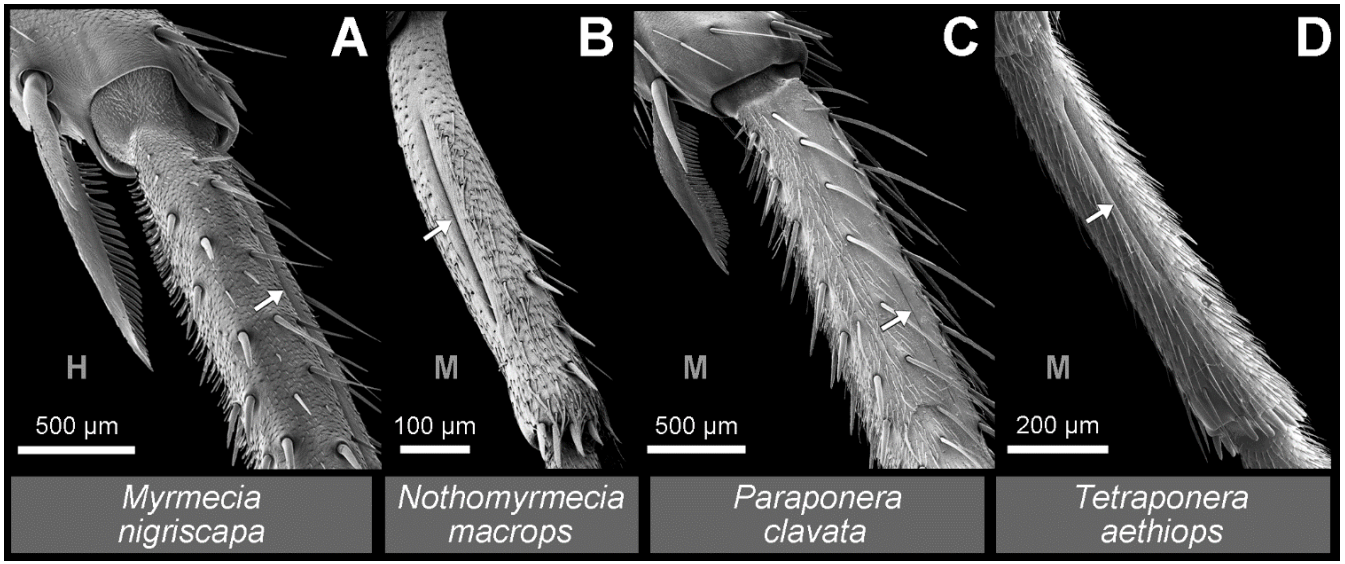

464 Fig. 3. Scanning micrographs of anterior face of basitarsus in workers of non-Amblyoponini 465 species, white arrows indicate basitarsal sulcus (grey $\mathrm{M}$ and $\mathrm{H}$ indicate midleg and hindleg 466 basitarsus, respectively). 


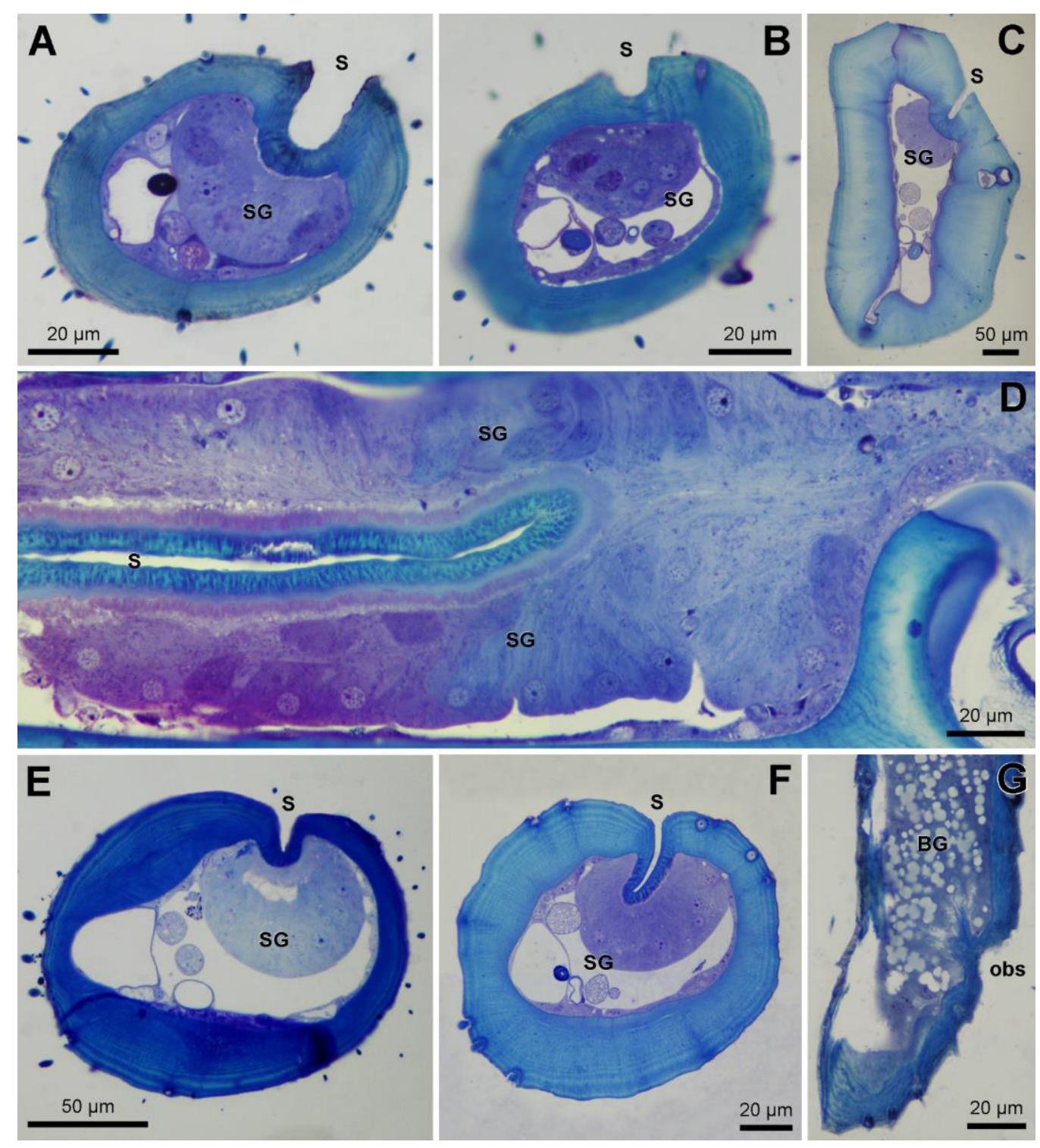

468 Fig. 4. Semithin sections through the worker basitarsus (frontal in image D, longitudinal in G, 469 transverse in all other images), showing the sulcus (S) and the epithelial basitarsal sulcus gland 470 (SG). A. Stigmatomma roahady midleg. B. S. roahady hindleg. C. Paraponera clavata midleg. 471 D. Myopopone castanea midleg. E. Tetraponera rufonigra hindleg. F. Nothomyrmecia macrops 472 hindleg. G. Onychomyrmex hedleyi hindleg. obs: oval basitarsal sulcus, BG: basitarsal gland. 

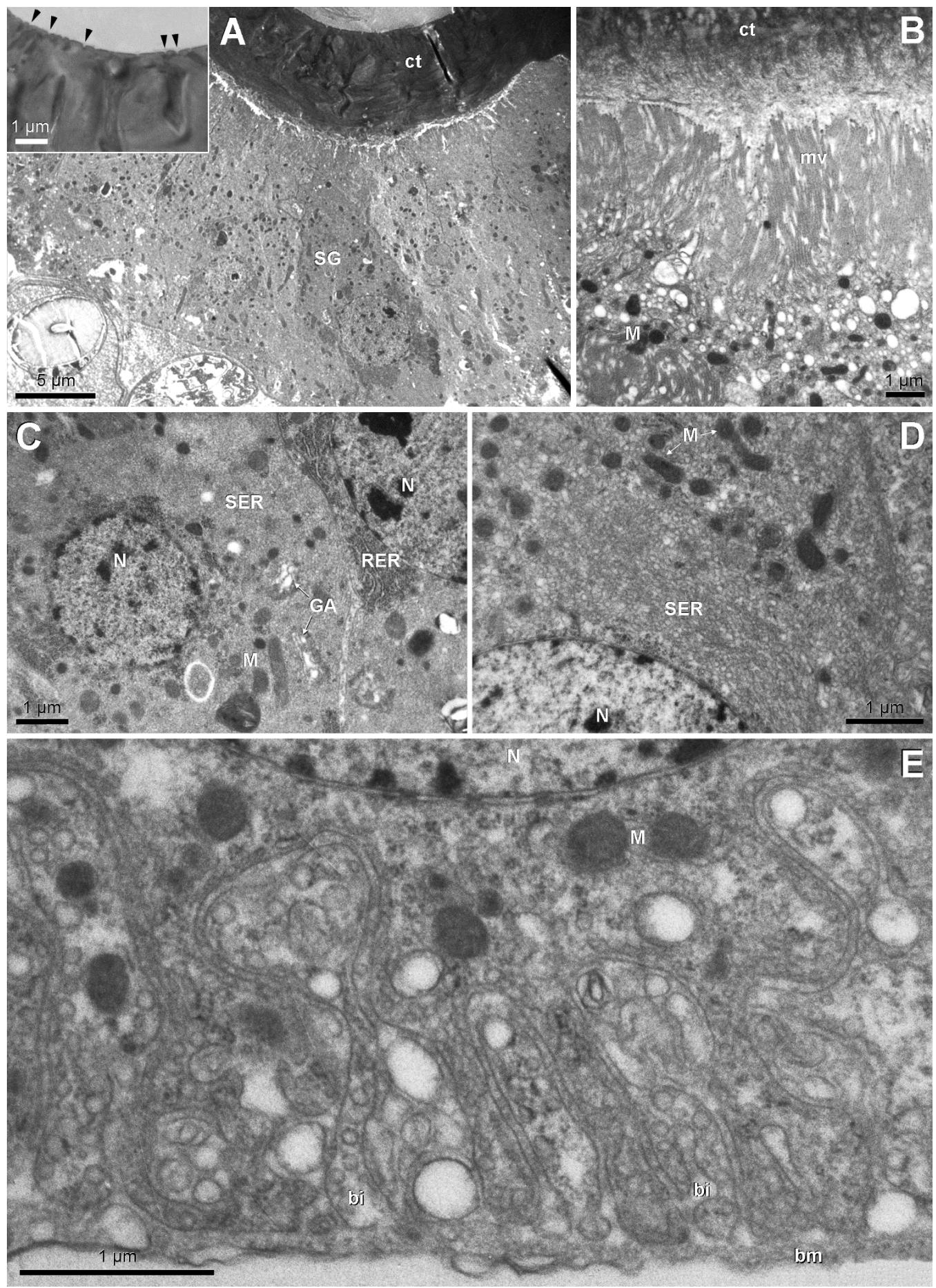

474 Fig. 5. Electron micrographs of the basitarsal sulcus gland. A. Overview of gland epithelium 475 (SG) underneath cuticle (ct) of Stigmatomma roahady midleg. Inset shows detail of cuticle 476 surface inside sulcus with minuscule cuticular depressions (arrowheads). B. Apical cytoplasm 477 of Paraponera clavata hindleg gland with microvillar border (mv). C. Detail of cytoplasm in 478 Stigmatomma roahady midleg gland, showing smooth (SER) and granular endoplasmic 479 reticulum (RER), well-developed Golgi apparatus (GA) and mitochondria (M). D. Central 480 cytoplasm of Myopopone castanea hindleg gland showing extensive smooth endoplasmic 481 reticulum (SER) and mitochondria (M). E. Basal cytoplasm of $M$. castanea hindleg gland with 482 prominent basal invaginations (bi). bm: basement membrane, $\mathrm{N}$ : nucleus. 

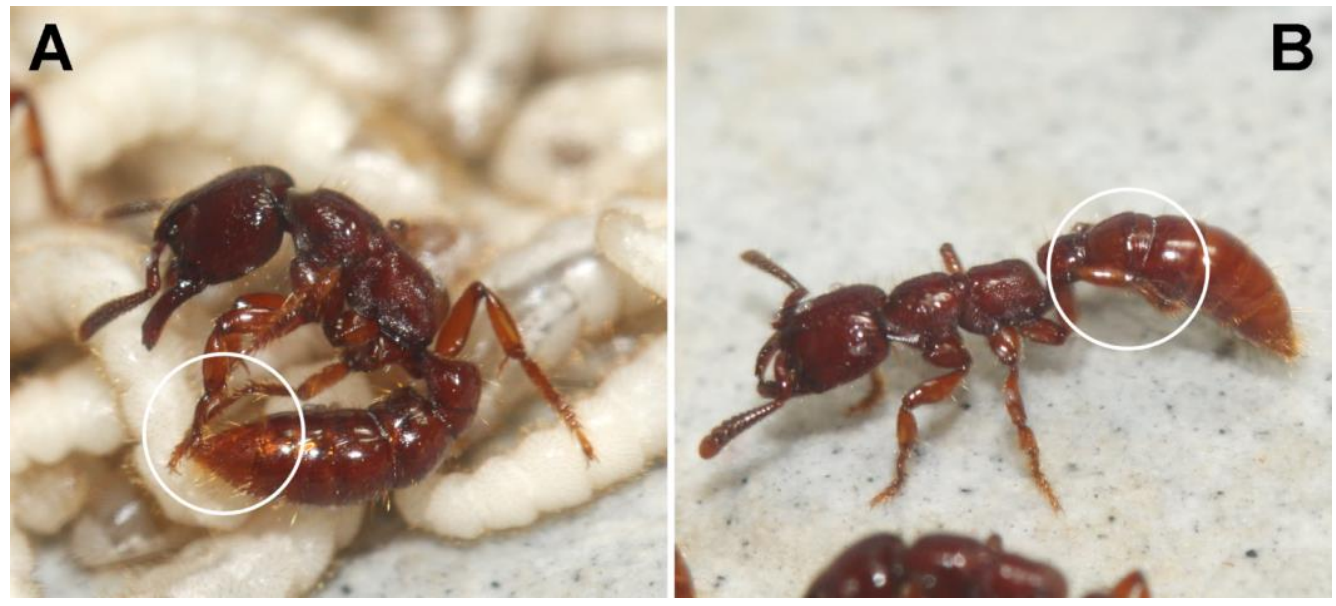

Fig. 6. Leg-rubbing behaviour (LR) of Myopopone castanea. A. Lateral leg-rubbing (LLR) 485 involves four legs and the gaster tip while the two remaining legs support the body. B. Posterior leg-rubbing (PLR) only involves the hindlegs, which are rubbed below the gaster while the ant is standing. Circles highlight the LR.

\section{Supplementary file legends}

490 Supplementary Video 1: Leg-rubbing (LR) behaviour in Myopopone castanea. The worker in 491 the top right corner performs posterior (PLR) and lateral (LLR) leg-rubbing.

492 Supplementary Video 2: Slow-motion playback of lateral leg-rubbing (LLR) in Myopopone 493 castanea. Basitarsi and tarsomeres touch during this behaviour.

494 Supplementary Table S1: Specimen and collection data of material examined in this study.

495 Supplementary Table S2: Distribution of the basitarsal sulcus in the specimens examined in 496 this study.

497 Supplementary Table S3: Myopopone castanea behavioural observation matrix. 